\title{
Novel ecosystems in the restoration of cultural landscapes of Tl'chés, West Chatham Island, British Columbia, Canada
}

Thiago C Gomes

\begin{abstract}
Introduction: The small archipelago of Tl'chés, in coastal British Columbia, has gone through drastic social-ecological change culminating in the decline of traditional management practices, invasion of exotic plant species and, in the early 1960s, land abandonment. This is a common trend in cultural landscapes around the world. Cultural landscapes have great social-ecological significance, including cultural safeguarding and renewal, as well as maintenance of biodiversity, ecosystem functions and services, making them objects of special attention in conservation and restoration efforts. This study investigates the relationship between the Lekwungen people and heavily altered ecosystems in the context of ecological restoration for the cultural landscapes of TI'chés.

Methods: In order to thoroughly explore the ecological, social and cultural aspects and processes involved in the restoration of Tl'chés, this study combined different environmental sciences methodologies, including historical and archival research, semi-structured interviews and participatory observation with Lekwungen participants, as well as ecological field assessments and an innovative mapping approach termed Terrestrial Cultural Ecosystem Mapping (TCEM).

Results: This study generated historical and spatial references for ecosystem and land use change in West Chatham Island, as well as cultural and ecological understandings to support restoration. Although important native species such as Camassia spp. are still thriving, present-day ecosystems on this island are heavily altered from the natural Garry oak ecosystem reference sites and are largely dominated by exotic invasive shrubs and graminoid species. This investigation indicates that the Lekwungen value both the historical ecological conditions of the island and particular types of the present-day novel or hybrid ecological states, such as the overgrown heritage orchard and nonnative berries found on the islands.
\end{abstract}

Conclusions: Present-day ecosystems of Tl'chés are a result of a hybrid management system (traditional and conventional), coupled with land abandonment for many decades. Restoration of Tl'chés must involve both ecological and cultural components. Therefore, intervention strategies should consider the incorporation of novel and hybrid ecosystems (i.e. naturalized exotic species) into a restoration plan for ecological, cultural, historical, and subsistence values.

Keywords: Ecological restoration, Novel ecosystems, Cultural landscapes, Traditional ecological knowledge and wisdom (TEKW), Historical ecology, Garry oak ecosystems, Lekwungen

Correspondence: gothiago@uvic.ca

School of Environmental Studies, University of Victoria, PO Box 3060 STN

CSC, Victoria, BC V8W 3R4, Canada 


\section{Introduction}

Tl'chés, the Lekwungen word for island (Mitchell 1968), is a small archipelago in the Inner Channels of the Salish Sea, off southeastern Vancouver Island (British Columbia). The archipelago comprises Discovery Island, the Chatham Islands and adjacent islets (Figure 1). For countless generations these islands have been vital for the livelihoods and cultural expression of Straits Salish peoples in the region, especially the Lekwungen people.

Lekwungen territory, which once extended through southernmost Vancouver Island (Canada) to western San Juan Island (USA), is presently limited to urban and semi-urban reserves in and around the present-day city of Victoria, British Columbia (Suttles 1974; Lutz 2009). The uninhabited archipelago of Tl'chés represents approximately two-thirds of Lekwungen reserve lands. Adjacent islands, as well as the southern portion of Discovery Island are under municipal and provincial tenure, including the Oak Bay Islands Ecological Reserve and Discovery Island Marine Park, which protect sensitive Garry oak (Quercus garryana Dougl.) associated ecosystems.

Garry oak (also known as Oregon white oak) is distributed in the Pacific Northwest region of North America. In Canada, Garry oak associated ecosystems occur mostly on southeastern Vancouver Island, in the rain shadow of the Olympic Mountains. Contained within the submediterranean climate of the Coastal Douglas-fir (CDF) zone, Garry oaks are found growing in infertile, acidic, and postglacial soils (Fuchs 2001). The Garry oak ecosystem is the most at-risk terrestrial ecosystem in Canada, with less than $5 \%$ of the original cover remaining today (Lea 2006; GOERT - Garry Oak Ecosystem Recovery Team 2010). Garry oak ecosystems play an important ecological role as habitat for particular fauna and invertebrates-over 100 native vertebrates are recognized in these ecosystems (Fuchs 2001; CRD - Capital Regional District 2011). Small islands such as Discovery, the Chatham Islands and the Gulf Islands in Canada and USA are important remnants of shallow soil Garry oak ecosystems. The archipelago of Tl'chés comprises an ecological mosaic of sensitive coastal bluffs, meadows, woodlands, vernal pools, lagoons and other wetlands (Ward et al. 1998). Red-listed species documented on the islands include California buttercup (Ranunculus californicus Benth.), Macoun's meadows-foam (Limnanthes macounii Trel.) and endangered sharp-tailed snake (Contia tenuis) (COSEWIC - Committee on the Status of Endangered Wildlife in Canada 2008).

Garry oak and associated ecosystems are believed to reflect the ecological imprint of intensive indigenous management practices over thousands of years. These practices include the use of a frequent low-level fire regime to support the production of important root vegetables, such as camas [Camassia quamash (Pursh) Greene and Camassia leichtlinii subsp. suksdorfii (Baker) S. Watson (Green.) Gould] (Figure 2) and also to maintain an open landscape for hunting (Boyd 1999; Turner 1999; Pellat et al. 2001; Beckwith 2004; Anderson 2005; Deur and Turner 2005; McDadi and Hebda 2008; Anderson 2009). Garry oak ecosystems were formerly a mosaic of vegetation types from open parklands on deeper soils to small plant communities on rocky outcrops (MacDougall et al. 2004). Paleoecological records from southeastern Vancouver Island and adjacent islands indicate that oak and associated ecosystems have been present in the region since the early and mid-Holocene within relatively steady geographic boundaries, withstanding variations from a drier to a moister climate (Heusser 1983; Hebda 1995; Allen et al. 1999; Pellat et al. 2001).

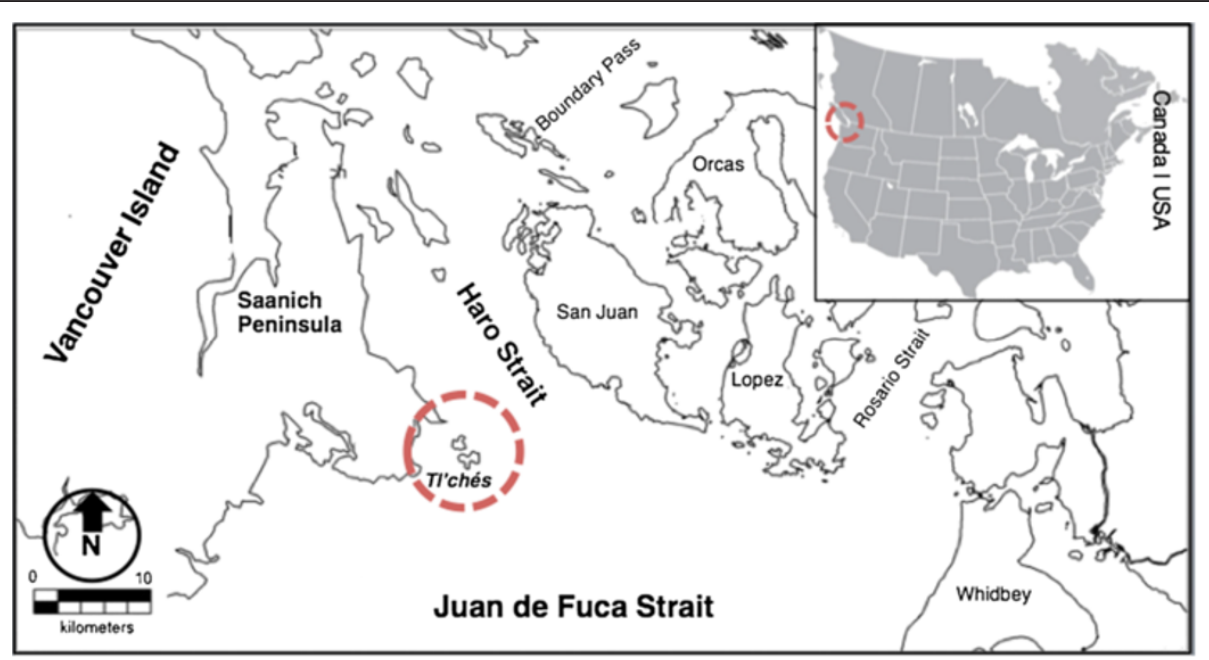

Figure 1 Location of Tl'chés archipelago, off southeastern Vancouver Island, British Columbia, Canada. 


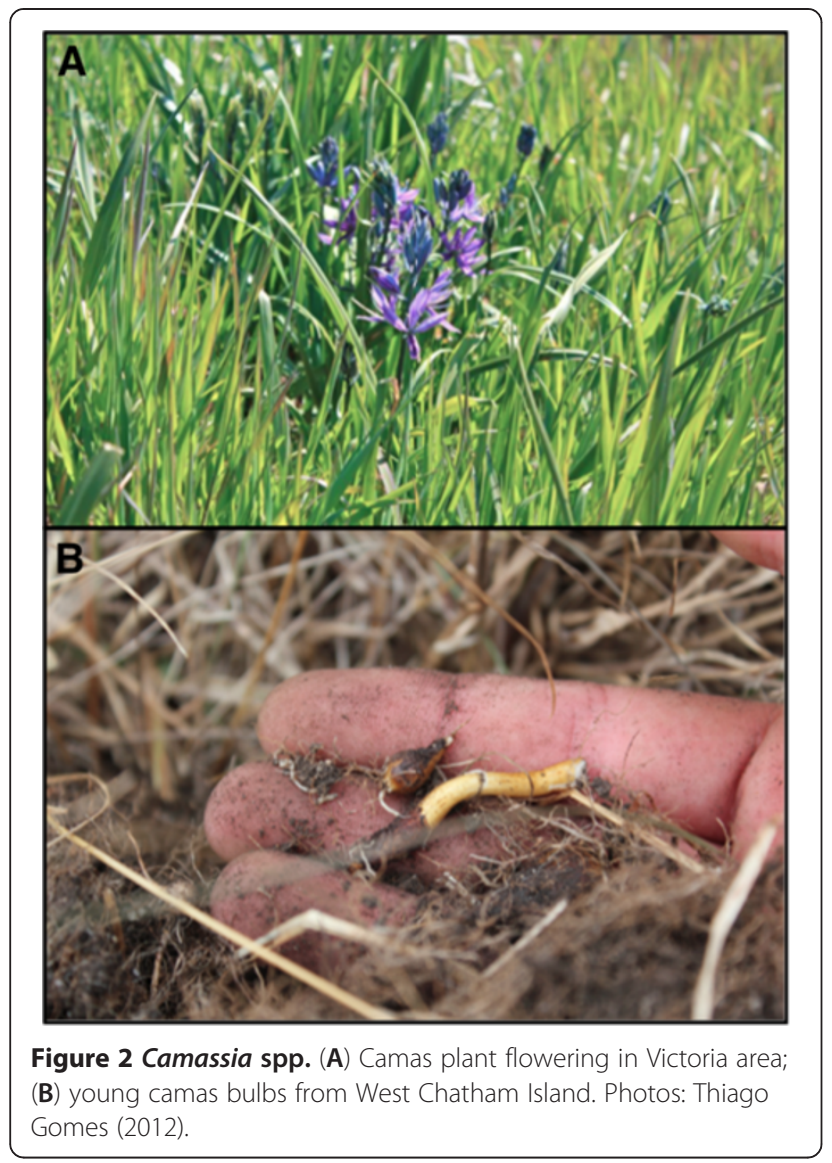

Fire suppression, habitat loss and invasion by exotic plant species are the main drivers for change in Garry oak ecosystems (MacDougall et al. 2004). In fact habitat degradation and biological invasions are among the main drivers for ecosystem change and biodiversity loss worldwide (Millennium Ecosystem Assessment 2005). As a result of increased social-ecological changes over the last century, including the encroachment by European settlers on the traditional lands of local First Nations, intensive urbanization (Lutz 2009) and the introduction of numerous exotic plant species, most deep soil Garry oak ecosystem remnants are highly fragmented ecological communities at best (Lea 2006).
These remnants are mostly confined to parks and preserves and void of traditional stewardship and management practices, such as traditional landscape burning.

In early 1960s the last Lekwungen families left the islands to join the main reservation in Esquimalt leaving Tl'chés uninhabited and largely untended. Since this loss of permanent inhabitants, Tl'chés has become increasingly vulnerable to different elements of environmental change, such as the invasion of exotic plant species and habitat degradation. Long-term separation of Lekwungen and the landscapes of Tl'chés has led to the loss of knowledge about traditional lifeways, management practices and local species, as well as cultural values and principles; such losses have been referred to as invisible losses (see Turner et al. 2008). Altogether, ecological and cultural losses contribute to a cumulative reduction in biocultural diversity (Maffi and Woodley 2010), a fundamental characteristic of the landscapes at Tl'chés.

The proximity of the archipelago to adjacent urban areas in southeastern Vancouver Island contributes to increased environmental pressures on the islands. Although Tl'chés has been a desired route and destination for outdoor recreation for decades, little infrastructure is present on the islands. The impact that these uninvited visitors were having on the islands led the Lekwungen to ban such activities within their traditional territory.

Environmental change facilitated by human action can shift ecosystems into different configurations of composition, structure or function. Novel ecosystems can arise from either abandoned cultivated land or natural areas, ushering in a process of change that exceeds historical biotic and abiotic ecosystem thresholds (Milton 2003; Hobbs et al. 2006) (Figure 3). The emergence of novel ecosystems poses special challenges to conservation and restoration ecology, both of which aim to mitigate abiotic changes and reverse biotic changes, pushing systems back towards historical and highly valued states (Hobbs et al. 2009).

\section{Restoring Tl'chés}

This study is founded on the understanding that Traditional Ecological Knowledge and Wisdom (TEKW) have

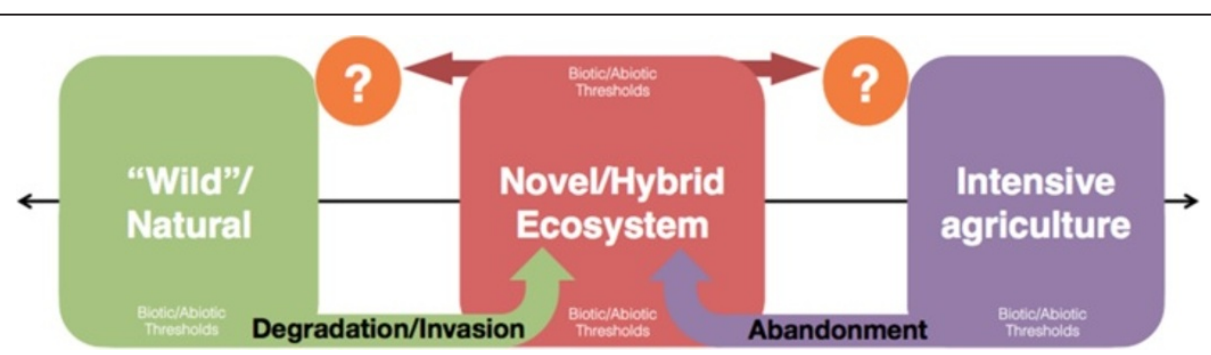

Figure 3 Emergence of novel ecosystems. Novel ecosystems arise either from the degradation and invasion of "wild" or natural systems, or from the abandonment of intensively managed systems, surpassing historical biotic and/or abiotic thresholds. Modified from Hobbs et al. (2006). 
a fundamental role in the restoration of cultural landscapes. Degraded Garry oak ecosystems require meticulous strategic planning for their conservation, stabilization and recovery, including the consideration of ecological and cultural aspects. Eco-cultural or ethnoecological restoration combines the interdisciplinary field of ethnoecology with the science of restoration ecology. This holistic, integrative and objective approach aims to promote the restoration of a degraded ecosystem, with respect to its ecological and cultural integrity as well as its sustainability towards a historical trajectory (Rogers-Martinez 1992; Society for Ecological Restoration International 2004; Higgs 2005; Turner 2005; Gomes 2012. An inspiration for this project is Lekwungen elder Joan Morris, Sellemah, who was raised by her great-grandparents and grandparents on Tl'chés. She is a knowledgeable leader in her community and a visionary for cultural renewal and ecological restoration on the islands. Sellemah longs to see the traditional gardens and orchards she remembers from her childhood on Tl'chés restored. She wants to see a healthier, more sustainable way of life as part of her people's relationship with their environment (see featured video).

In this context, this research was designed to explore the relationship between people and Tl'chés, and how this knowledge can be used in planning restoration intervention strategies for the promotion of ecological and cultural integrity and long-term sustainability for the people and ecosystems of Tl'chés.

\section{Methods}

This study was designed to generate historical and spatial references, including both cultural and ecological understanding, to inform ethnoecological restoration of Tl'chés. Qualitative methods, including historical and archival research, semi-structured interviews with Lekwungen participants, participatory observation, ecological field assessments and mapping, were employed. Due to time and resource limitations, field investigations were restricted to West Chatham Island.

\section{Historical and archival research}

Archives and collections from the University of Victoria Maps Library, the BC Archives and the Anthropology Audio-Visual Collection at the Royal British Columbia Museum were visited for historical aerial and ground photographs, maps, drawings, written and audio documents that hold information on the ecological history of Tl'chés. Ethnographic and anthropological literature was consulted for an understanding of social-ecological processes and livelihoods of past inhabitants on the Chatham Islands.

Research materials were organized and categorized for analysis and processing and arranged in a timeline for exploring land use change over time. Aerial photographs of the site for the last 80 years were available. The best resolution images were selected and arranged with the assistance of GIS software to illustrate the gradient of landscape change over time.

\section{Semi-structured interviews and participatory observation}

Semi-structured and open-ended interviews were conducted with three distinct groups of Lekwungen people: Elders, community leaders and youth. Elders were mostly questioned about cultural context, memories and experiences, TEKW related to place, environmental change and directions for future land use and restoration for Tl'chés. Community leaders and youth were interviewed about their relationship with Tl'chés, and future directions for land use and restoration of the islands. Participatory observations were made during fieldwork and cultural gatherings on Tl'chés.

Interview materials and notes were analyzed after each interview on a continuous basis. This ongoing analysis allowed for better understanding and improved planning of future meetings. Interviews were then transcribed and organized in files for processing and further analysis. Analysis of qualitative interview data followed classic methodology for identifying themes, patterns and relationships in each interview separately, subsequently crossing and comparing with other interviews in order to check for consistency of information (Bernard 2002; Ryan and Bernard 2003).

\section{Ecological assessments and Terrestrial Cultural Ecosystem Mapping (TCEM)}

Terrestrial Cultural Ecosystem Mapping is a mapping approach specially adapted from different methodologies to enhance surveying and mapping capacity for ecosystems within cultural landscapes. Most field visits for ecosystem surveys and mapping were made alongside a Lekwungen participant. Field assessments followed standards and procedures from the Field Manual for Describing Terrestrial Ecosystems (Province of British Columbia 2010), as well as specific cultural protocols. A GPS unit recorded tracks for all paths travelled during fieldwork, and waypoints were marked in places of important observations noticed by surveyors. Descriptive photographs and plant collections accompany waypoint field notes. The lack of random survey plots encouraged a more fluid survey approach, making use of local informants' insights and direction, along the lines of a rapid appraisal survey approach (Cunningham 2001; Herrick et al. 2005). These surveys included the identification and mapping of ecosystem types, environmental conditions, dominant species, indicator species, invasive species and culturally significant species, as well as other important cultural and historical features of the landscape. 
Voucher specimen collection followed ethnobotanical procedures and classic botanical methodologies (Cunningham 2001). Specimens were identified and deposited in the Ethnobotanical Collection at the University of Victoria's Herbarium.

Open source QGIS (Quantum GIS) software was used for spatial data processing and map design. Digital maps containing field notes, photographs and cultural background for different ecosystem sub-types were generated.

\section{Results and discussion}

Tl'chés is a dynamic social-ecological system. Such systems are considered multi-equilibrium, occurring in diverse combinations of social and ecological relationships (Berkes and Turner 2006). The very subsistence of both cultural and ecological entities is dependent upon these dynamic and cyclical systems. Oral history, memories, historical reports, maps, photographs, ecological assessments and interviews reveal that human influence (presence or absence) has guided ecosystem structure, function and processes across the landscape of Tl'chés.

\section{Land use change and livelihoods in Tl'chés}

One of the earliest oral history accounts for Tl'chés offers detailed information on local geography, salmon ecology and seasonal availability, fishing technology, and the traditional use and ceremonial significance of native plants on the islands (Jenness n.d.; Turner 2005). This information, portrayed in the "Origin of Salmon" narrative, is supported by ethnographers' accounts and knowledge holders interviewed in the present study.

Boas (1890), Hill-Tout (1905) and Suttles (1974) all point to the early occupation of the islands as temporary or permanent fishing villages (Table 1). During the 1862-63 smallpox epidemic they served as a refuge for Indigenous Peoples in the region (Duff 1969; Lutz 2009). European settlement in southernmost Vancouver Island and the signing of the Douglas Treaties (1850-1854) changed Lekwungen lifeways and livelihoods dramatically by encroaching on traditional lands and limiting fishing rights, as well as imposing waged work on Indigenous Peoples in agriculture, fishing, canneries and housekeeping (Lutz 2009).
The arrival of introduced plant and animal species and new technologies to the region (see White 1980) also significantly influenced indigenous livelihoods. Lutz (2009) speaks of a "moditional economy" practiced by Indigenous Peoples living around Fort Victoria. This meant participating in the wage economy by working for salaries during a certain time of the year in order to maintain traditional practices for the rest of the year, thus boosting the traditional potlatch "prestige economy". In fact, these processes of a mixed economy have been observed in other post-contact societies facing social-ecological changes, such as the First Nations in the Northwest Territories (Asch 1979).

Tom James, Sellemah's grandfather, reported to the McKenna-McBride Royal Commission in 1913 that he fished salmon, halibut and cod for four months and would sell his catch to the local market. He also worked at the cannery in Esquimalt and would travel for 23 weeks a year to the USA to work picking hops. If he needed to make extra money, he would sell some of his sheep from Tl'chés (McKenna-McBride Royal Commission 1913). The hybridization in economics and ecology described by Lutz (2009) was present at Tl'chés. For instance, these islands were central for the continuation of traditional Straits Salish culture during times of legal prohibitions of traditional potlatch ceremonies and winter (also known as spirit) dances in the region (Suttles 1974; Lutz 2009; Joan Morris pers. comm. 2011). At the same time, however, traditional land management practices were already being merged with introduced technologies and new species as local livelihoods adapted to these times of drastic social-ecological change.

During the first half of the twentieth century, Joan Morris' (Sellemah) immediate family managed and tended the islands. Locals lived as fishermen, with only about 5 ha of "gardens and grass spots adjacent to ranchers", and about 10 ha of pasture for over 180 sheep, about 100 chicken and fowl, a few cows and one horse, spread over all islands of Tl'chés (McKenna-McBride Royal Commission 1913). Fishing was still the main source of subsistence, but it was paired with intense use of terrestrial ecosystems and hybrid agricultural techniques. Sellemah speaks of her days living on the Chatham Islands, when introduced animals shared space with native

Table 1 Tl'chés timeline for land use change

\begin{tabular}{|c|c|c|c|c|c|c|c|}
\hline Before 1800 s $1862-1863$ Late 1800 s & Early 1900s & 1940s 1960s & 1970s & $1980 \mathrm{~s}$ & Late 1990s & 2011 & Future \\
\hline Summer fishing villages & \multicolumn{2}{|c|}{ Hybrid cultivation } & \multicolumn{2}{|c|}{ No mgmt. (Idle) } & Restore mgmt. system & \multicolumn{2}{|c|}{$\begin{array}{l}\text { How to best } \\
\text { intervene? }\end{array}$} \\
\hline Reef net locations & \multirow{2}{*}{\multicolumn{2}{|c|}{$\begin{array}{c}\text { Camas + non-native vegetable } \\
\text { gardens and orchards + sheep + } \\
\text { chicken + fishing }\end{array}$}} & \multirow{2}{*}{\multicolumn{2}{|c|}{$\begin{array}{l}\text { Disturbance + invasive } \\
\text { species establishment }\end{array}$}} & \multirow[t]{2}{*}{ Traditional fire mgmt + seeds } & \multirow{2}{*}{\multicolumn{2}{|c|}{$\begin{array}{l}\text { Resilience + long- } \\
\text { term sustainability }\end{array}$}} \\
\hline $\begin{array}{l}\text { Traditional cultivation, } \\
\text { Fishing + camas cultivation }\end{array}$ & & & & & & & \\
\hline Refuge during smallpox epidemic & & & & & & & \\
\hline
\end{tabular}


frogs, snakes, otters, seals, seagulls, crows and other birds. Sheep were raised for wool, and introduced chickens and resident seagulls (Larus glaucescens) provided eggs. Native bulbs and rhizomes, such as camas (Camassia spp.), chocolate lily [Fritillaria affinis (Schult.) Sealy var. affinis], silverweed (Potentilla egedii Wormsk. L.), springbank clover (Trifolium wormskioldii Lehm.), and bracken fern [Pteridium aquilinum (L.) Kuhn] were produced concurrently with introduced tubers, bulbs, and vegetables such as peas, potatoes, carrots, onions, rhubarb, celery, turnips, cabbage and barley. Native berries were harvested throughout the islands, whereas heritage apple and plum varieties were cultivated in an orchard area adjacent to the homestead. Along the coast, sea urchins (Strongylocentrotus spp.) could be easily harvested in bull kelp (Nereocystis luetkeana) forests, as could oysters and clams from intertidal beds (see Additional file 1, Joan Morris pers. comm. 2011).

A significant environmental episode in the late 1950s forced families to gradually move back to the inland reservations. Fresh water availability dramatically changed in cisterns and wells in both Chatham Islands and Discovery Islands (Joan Morris pers. comm. 2011, Skippy and May Sam pers. comm. 2011). These structures were likely fed by rainwater. Sellemah confirmed that "the well went dry," so her family did not have enough water to support themselves and the animals on the island. Decades earlier, Lekwungen Harry Williams had noted that water quality was a concern for those raising cows, as some of the cattle brought to the islands had died (McKenna-McBride Royal Commission 1913). Recurrent drier-than-normal summers accompanied by potential fluctuation in rainwater led to the movement of the last Lekwungen families off of Tl'chés by the late 1950s and early 1960s (Joan Morris pers. comm. 2011; Skippy and May Sam pers. comm. 2011).

Aerial photographs of West Chatham Island, dating from 1930 to 2005, assisted in identifying landscape and land use change (such as vegetation cover and canopy dynamics), disturbances (such as fires or floods), and buildings (such as outlines of homesteads, fences, pathways, cistern structures and dock areas) (Figure 4, see Additional file 2).

A trend shown in the gradient of images is the reduction in tree cover and variation in the shrub and herb layers. Use of timber for building structures for the farmstead, docks and possibly canoes and the need for open space for sheep grazing have likely played an important role in thinning some of the woodland areas. Sellemah remembers the woodland understory as more open and clearer than today (Joan Morris pers. comm. 2011). Grazing within fences likely depleted vegetation biomass, and the introduction of agronomic grasses to supply fodder for sheep was a common practice in the region (White 1980). Land abandonment and accidental fires were also fundamental

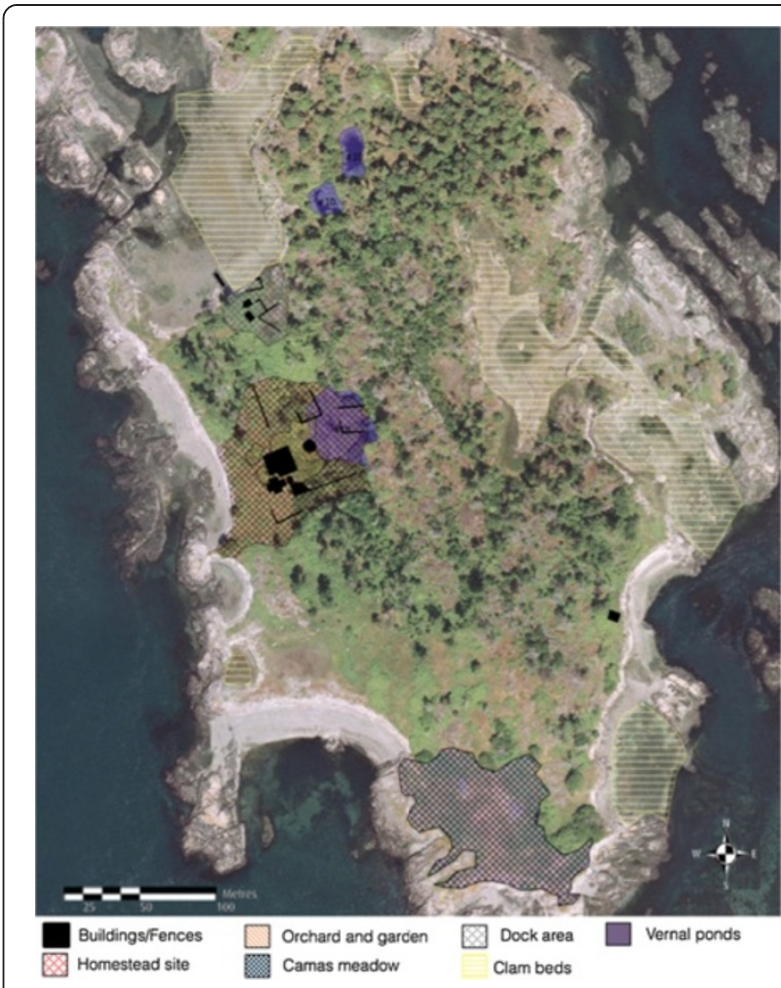

Figure 4 West Chatham Island historical and cultural features: buildings, homestead site, dock area, orchard and garden sites, camas meadow, clam beds and vernal ponds.

in changing the island ecosystems, especially facilitating the introduction, establishment and dominance of invasive Himalayan blackberry (Rubus armeniacus Focke) from the 1960s onwards.

Today, Lekwungen do not rely on the islands for their livelihoods. However current restoration efforts could guide the future for Tl'chés land use. Restoration planning for these islands must take into consideration the successional trends and climate change predictions for the CDF region, i.e. conifer encroachment and the arrival of new exotic species due to wetter climate conditions and suppression of traditional indigenous fire practices (MacDougall and Turkington 2005; Hamann 2006; Wang et al. 2012) as well as the renewal of human-ecosystems interactions.

\section{Novel restoration strategies for novel ecosystems}

The ecosystems of Tl'chés have been heavily altered and are dominated by a combination of invasive species such as Himalayan blackberry, English ivy (Hedera helix L.), Scotch broom [Cytisus scoparius (L.) Link.] and agronomic grasses (Bromus tectorum L., Holcus lanatus L., Anthoxanthum odoratum L.). TCEM and ecological assessments identified 10 different ecosystem sub-types based on physiognomy, plant associations, location, and cultural and historical significance. Assessments revealed 
Table 2 Area cover of invasive species in West Chatham Island

\begin{tabular}{|c|c|c|c|c|c|}
\hline Invasive species & & Family & Area (ha)* & Percent cover & Distribution \\
\hline Himalayan blackberry & Rubus armeniacus Focke & Rosaceae & 14.3 & 85.2 & Throughout \\
\hline \multicolumn{6}{|l|}{ Agronomic grasses: } \\
\hline cheat grass, & Bromus tectorum L. & Poaceae & 1.9 & 11.4 & Throughout \\
\hline velvet grass, & Holcus lanatus L. & & & & \\
\hline sweet vernal grass & Anthoxanthum odoratum L. & & & & \\
\hline Scotch broom & Cytisus scoparius (L.) Link & Fabaceae & 0.36 & 2.2 & Eastern bluffs \\
\hline English ivy & Hedera helix L. & Araliaceae & 0.14 & 0.8 & Throughout \\
\hline Canada thistle & Cirsium arvense (L.) Scop. & Asteraceae & 0.06 & 0.4 & Southern bluffs \\
\hline Daphne & Daphne laureola L. & Thymelaeaceae & $\mathrm{n} / \mathrm{a}$ & - & Centre and north \\
\hline English holly & Ilex aquifolium L. & Aquifoliaceae & n/a & - & Northern woodland \\
\hline Himalayan cotoneaster & Cotoneaster simonsii Bak. & Rosaceae & $\mathrm{n} / \mathrm{a}$ & - & Northern woodland \\
\hline Common hawthorn & Craetegus monogyna Jacq. & Aquifoliaceae & $\mathrm{n} / \mathrm{a}$ & - & Centre and north \\
\hline Hairy cat's ear & Hypochaeris radicata $\mathrm{L}$. & Asteraceae & $\mathrm{n} / \mathrm{a}$ & - & Southern bluff \\
\hline Evergreen blackberry & Rubus laciniatus Willd. & Rosaceae & $\mathrm{n} / \mathrm{a}$ & - & Northern bluff \\
\hline Total invasive species & & & 16.8 & 100 & West Chatham Is. \\
\hline
\end{tabular}

*Values are conservative and imprecise based in non-quantitative field sampling.

that roughly less than $10 \%$ of West Chatham Island is free of invasive or nonnative species (Table 2).

Nonetheless, cultural imprints such as shell middens, burial cairns, culturally modified trees and sacred sites can still be found on the islands. Camas, a cultural keystone species in the region (see Garibaldi and Turner 2004) still thrives on West Chatham Island. A few populations of camas have been identified and mapped in coastal bluffs and meadow areas (Figure 2). However, at the same time that ecosystems on the islands have become more vulnerable to environmental pressures, so have culturally significant sites also been put at risk. Suppression of indigenous prescribed fires on Tl'chés has had a major effect on the structure, function and composition of coastal bluffs, meadows and woodland ecosystems. The loss of fire has facilitated regeneration of many fire-intolerant conifers, deciduous trees, shrubs and invasive species in open habitats throughout the island.

Most ecosystems on Tl'chés have been modified in their biotic and/or abiotic characteristics from historical states. These systems are hybrid systems, possibly in transition to novel ecosystems, in which restoration to historical conditions might be not possible (Hobbs et al. 2009) (Figure 5). Likewise, the social and economic configurations of the archipelago have drastically changed from a lively and functioning fishing village and farmsteads up until the 1950s to the present-day uninhabited islands, where only the occasional visits occur for recreation and cultural purposes. However, the cultural significance of the islands has persisted throughout the decades and has been critical to restoration endeavors (Joan Morris pers. comm. 2011).

Human intervention in the form of restoration is important to place the social-ecological systems of Tl'chés onto a trajectory for recovery, whether it is an intentional and well-planned intervention towards a historical trajectory or towards an alternative hybrid state aimed at enhancing a specific ecosystem service or

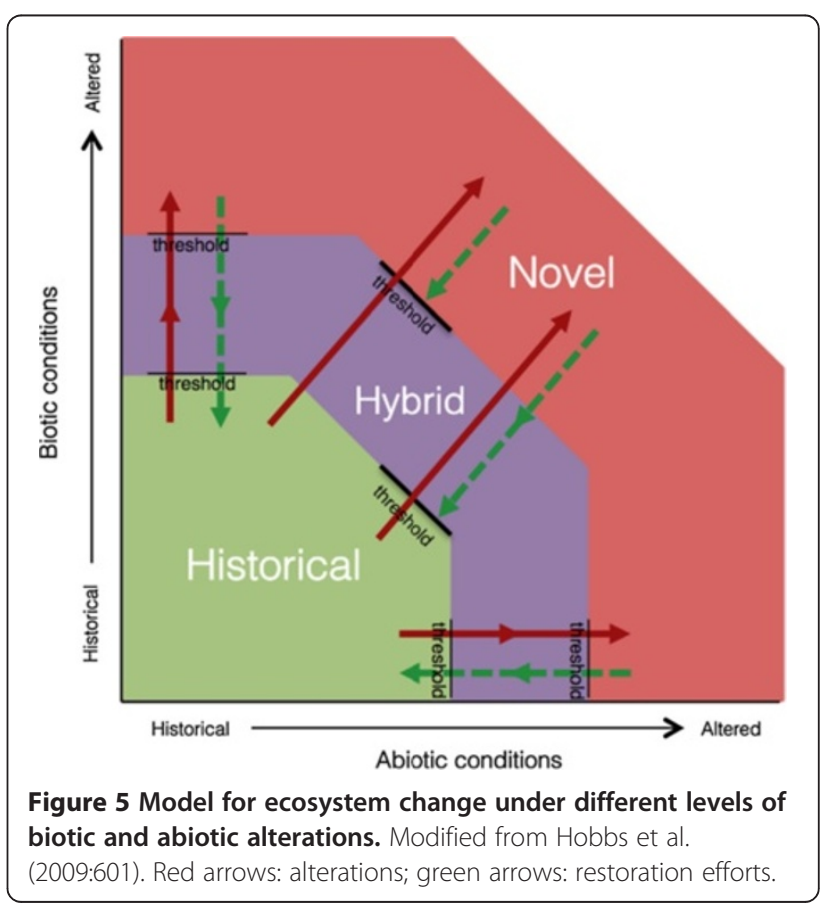


function (Hobbs et al. 2011). A trajectory of recovery towards a historical or natural ecological condition might be unfeasible in some cases, for example, when target ecosystems have been altered beyond biotic or abiotic thresholds or when it is too costly to take an altered ecosystem back to its historical state. In these cases setting of goals for restoration should focus on hybrid states that maintain resilience and highly valued functions and services (Hobbs et al. 2009). In a cultural landscape with heavily altered ecosystems such as Tl'chés, a recovery path does not necessarily involve reverting ecosystems to pre-contact states but should consider and encourage traditional lifeways, protect sensitive native species, and retain valued nonnative species.

\section{Heritage orchard and restoration}

The heritage orchard site has become a focal point for restoration at Tl'chés (see Higgs 2003). This site is one of the most visible and recent remnants of Lekwungen presence on the islands. The orchard remnant is located adjacent to where the homestead and cistern used to be (see Additional file 3). This site carries a deep socialecological and cultural significance for the Lekwungen participants. All of the fruit trees in this orchard were planted by Sellemah's great-grandmother and grandmother, including a mid-1800s heritage "American Mother" apple variety (Malus $\times$ domestica) (Figure 6), a couple of unidentified crabapple cultivars (Malus spp.), sweet cherry trees (Prunus avium L.) and two unidentified heritage plum varieties (Prunus domestica L.). This orchard is completely overgrown. As the orchard has been without management for more than 50 years, fruit production in the older trees is minimal, and hundreds of plum saplings form a dense 1.5-2 $\mathrm{m}$ tall thicket (Figure 7). Although the species in this orchard are nonnative, Lekwungen participants have selected this site as one of the priority sites for restoration, especially for the historical and cultural meaning of the fruit trees and their proximity to the old homestead. The Lekwungen are also interested in protecting the rare cultivar varieties at this site. Careful pruning of older trees, transplantation of young saplings and grafting of heritage varieties are included in the restoration action plan for Tl'chés.

Lekwungen participants have also indicated their interest in having more edible native species throughout the islands, particularly species found in small numbers such as trailing blackberry [Rubus ursinus subsp. macropetalus (Douglas ex Hook.) Roy L. Taylor \& MacBryde], Saskatoon berry [Amelanchier alnifolia (Nutt.) Nutt. ex M. Roem.], and the more abundant Pacific crabapple [Malus fusca (Raf.)]. All of these are very likely to be incorporated in the orchard site restoration, along with economically and historically important nonnative species, creating a hybrid mosaic of traditional and introduced edible plant species.

\section{Adaptive management and restoration: novel ecosystems and cultural ecosystems}

Local adaptation is an important part of landscape or resource management. Complementary to scientific knowledge, TEKW is regarded as adaptive management per se, being a natural or adaptive response towards resilience. TEKW is based on observations and monitoring of a specific resource or environmental variable, and it is ultimately maintained by social mechanisms (Berkes et al. 2000; Berkes and Turner 2006). For Tl'chés, Lekwungen

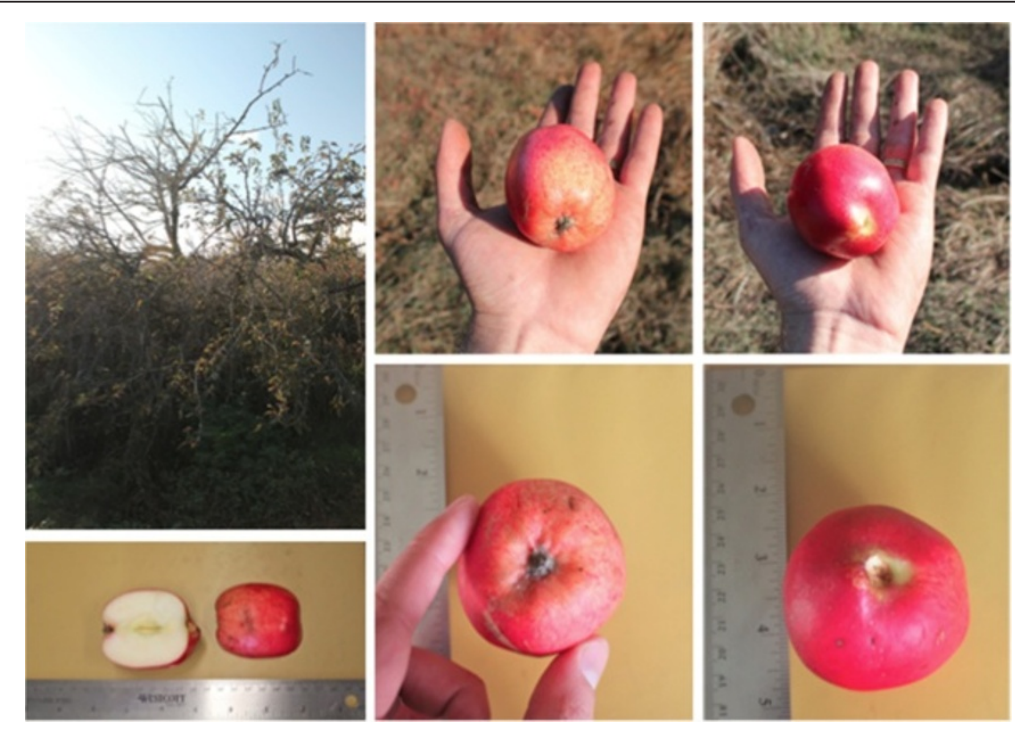

Figure 6 Heritage "American Mother" apple variety from overgrown orchard in West Chatham Island. Photos: Thiago Gomes (2012). 


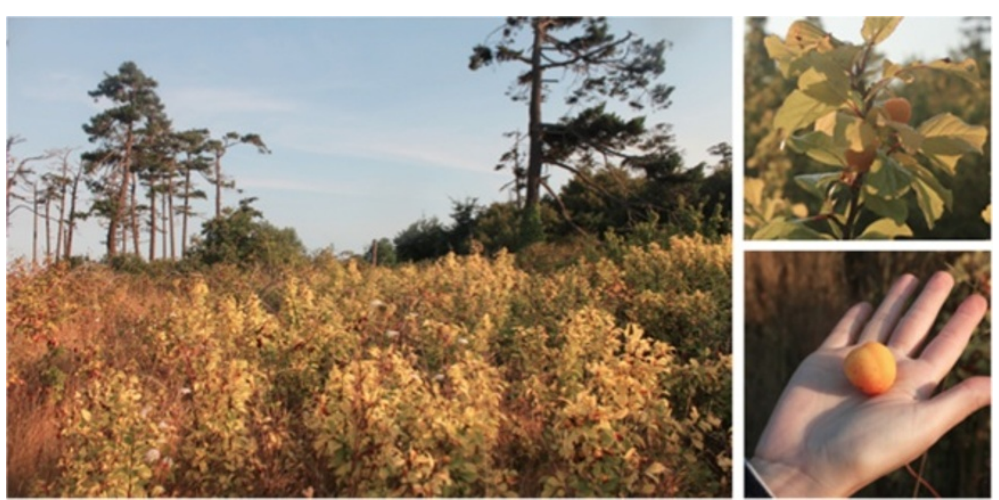

Figure 7 Heritage orchard in West Chatham Island. Plum saplings. Photos: Thiago Gomes (2012).

elder Sellemah holds a cumulative body of knowledge acquired during her years spent with her grandparents and great-grandparents. Now Sellemah and other Lekwungen Elders pass down this knowledge to young leaders and participants through the development of this restoration project. Sellemah led community participants to agree on TEKW principles and values for guiding restoration interventions on the islands. These principles and values have been documented and applied to restoration planning and actions, under the themes "Going back to our roots" and "Healing the land, healing the people" (see Additional files 1 and 4).

During this study, adaptive management and restoration strategies for Tl'chés emerged from the ecological assessments, mapping, and planning, and while undertaking restoration activities, work parties for the removal of specific invasive species, and traditional celebrations such as pitcooks (Figures 8 and 9).

For sites dominated by aggressive and well established invasive Himalayan blackberry, Scotch broom, English ivy and agronomic grasses, where complete removal is not feasible, alternative pathways based on long-term and holistic perspectives have to be considered as viable restoration strategies. For instance, although Himalayan blackberry dominates much of the shrub layer on the islands, outcompeting native shrubs, it also provides important ecosystem services such as habitat and food for avifauna. Blackberry fruit productivity is reasonably high, and berries could be harvested for fresh fruit consumption, jelly making, and as a healthy food (rich in antioxidants). Alongside berry harvesting, manual control and removal of invasive blackberry stalks can be done as an effective control strategy. Stalks could be broken off and used as mulching material, similarly to what some Indigenous People have done in their gardens elsewhere (Nancy Turner pers. comm. 2011, describing practices of Dr. Margaret Siwallace of Bella Coola, as observed in 1972). Scotch broom becomes a tall shrub when mature, and disposing of these bushes is challenging. The hard wood of mature broom can possibly be employed for tool making or related uses. In Europe, farmers use broom as green manure and as a preferred fuel for bread ovens. Common dandelion (Taraxacum officinale L.), hairy cat's ear (Hypochaeris radicata $\mathrm{L}$.), and sheep sorrel (Rumex acetosella L.) can also be harvested for their medicinal and nutritional values, as a strategy for gradual removal.

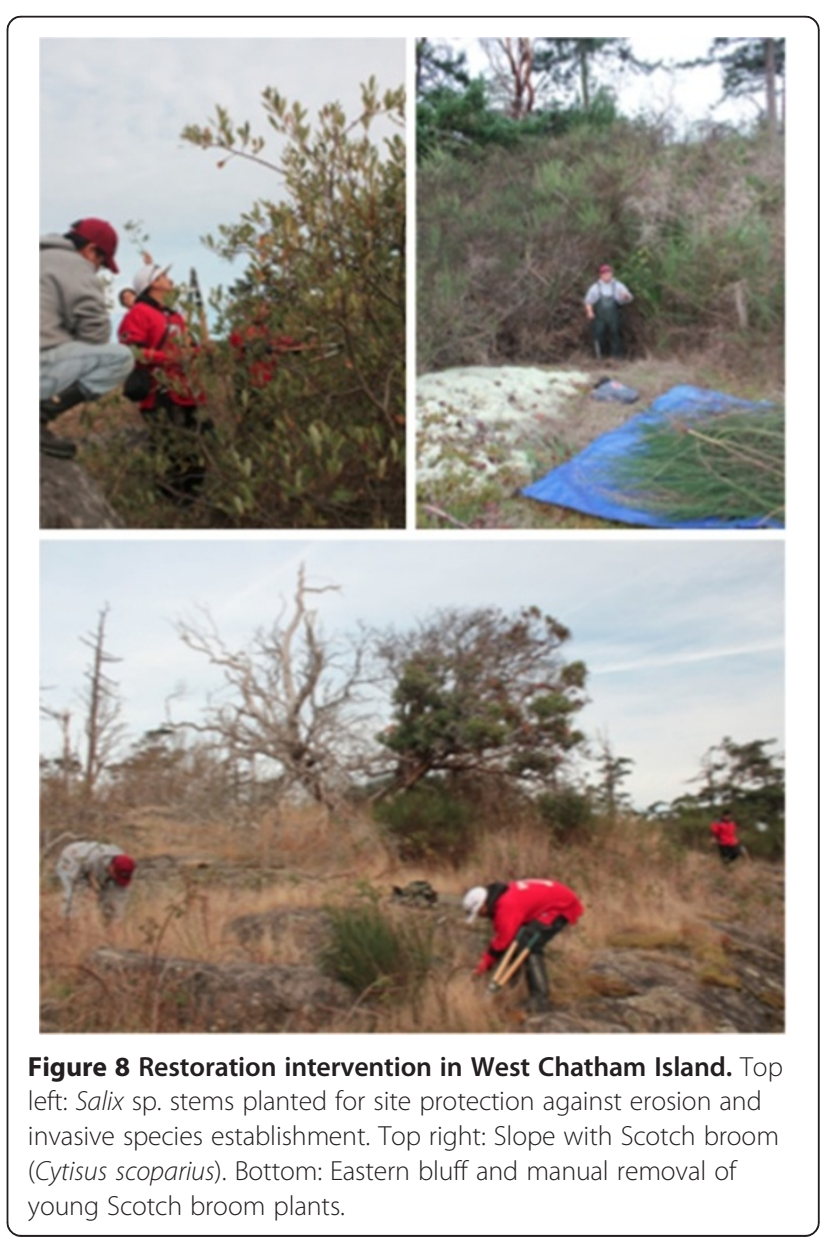




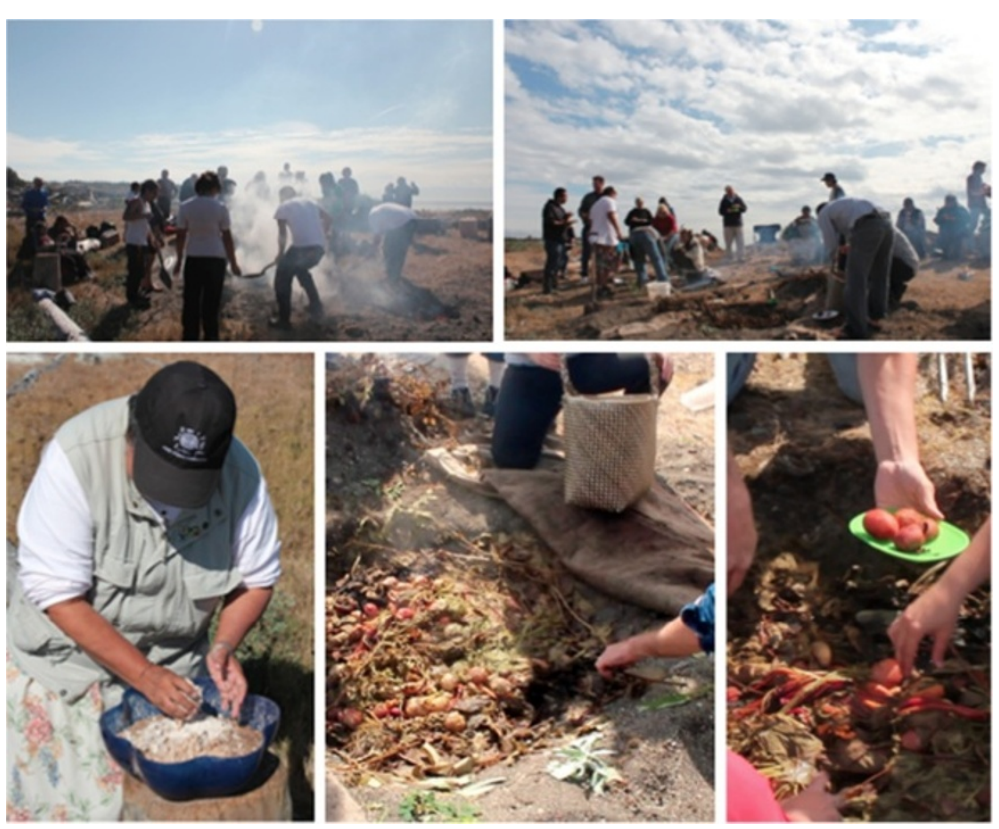

Figure 9 Traditional pitcook on West Chatham Island. Top left: Removing ashes. Top right: Sharing pitcook vegetables. Bottom left: Sellemah preparing bannock. Bottom centre and bottom right: Open pit with vegetables.

Garry oak ecosystem species such as the cultural keystone camas and other geophytes require intentional intervention including propagation to establish populations in other areas on the island. It is important to remember that these native ecosystems are the result of thousands of years of indigenous adaptive management. Some of these species are not thriving due to the high rate of invasion and niche competition as well as their specific demands for soil, climate, disturbance regimes, especially controlled burning, and dispersal assistance through seeding, harvesting and replanting. Re-establishment of indigenous fire management is part of the valuable adaptive knowledge for promoting the establishment of fire-adapted species, maintaining open landscapes, and controlling invasive agronomic grasses and other fireintolerant invasive species.

Indigenous management and cultural presence in Straits Salish landscapes have been rekindled with traditional pitcook celebrations as a strategy for cultural renewal and learning opportunity for younger generations. Although they are still called traditional, these have become somewhat hybrid or moditional. An example is the pitcook held on September 2011 on West Chatham Island (Figure 9). This pitcook did not use all ingredients and elements of a traditional pitcook (as described in Suttles 2005, Joan Morris pers. comm. 2011) but was instead creative and adaptive to local conditions. Since there were not enough camas or chocolate lily bulbs available to feed $30-40$ people, more readily acquired vegetables-such as potatoes, carrots, plantain, onions and garlic-were bought at a farmer's market and brought to the island. To envelop and cover the food within the pit salal (Gaultheria shallon Pursh.) and grand fir [Abies grandis (Douglas ex D. Don) Lindl.] boughs and sword fern [Polystichum munitum (Kaulf) C. Presl.], Nootka rose (Rosa nutkana C Presl.) branches and oceanspray [Holodiscus discolor (Pursh.) Maxim.] were also brought from off island, owing to the low availability of these resources on the island. Sea asparagus [Salicornia pacifica (Standley) A.J. Scott] from the upper tidal areas of the island was used to add extra "flavor" in this local adaptation.

A narration of local adaptation in the region was explored by Suttles (1951) about the processes by which the South American potato (Solanum tuberosum L.) was incorporated by First Nations in North America's Pacific Northwest. He chronicled its establishment as a staple food, gradually displacing native bulbs, such as camas. Suttles argued that the high nutritional content and simple propagation techniques of the potato, along with the existing technology and economy for geophytes were fundamental to the assimilation of this nonnative tuber in local social-ecological systems (Suttles 1951). These processes can be interpreted as an ecological analogy to Lutz's (2009) moditional economy practiced by Indigenous Peoples. In this moditional ecology, useful native species are outcompeted by nonnative ones due to ecological competition and/or human preference, while native species are preserved mostly for ceremonial and cultural purposes. It is likely that this has been the case at Tl'chés 
and throughout Indigenous communities in order to support traditional ways of life. Possibly, a moditional ecology or hybrid adaptive model might be the most appropriate model for the processes of continuous restoration and intervention actions at Tl'chés.

Lekwungen might value a hybrid system because of a stronger attachment to their more recent cultural history when compared with the historic ideals of Garry oak associated ecosystems. The fact that Camassia spp. bulbs are no longer consumed owing to insufficient stocks in deep soil Garry oak ecosystems, as well as lost knowledge regarding proper cooking and preparation (Beckwith 2004; Joan Morris pers. comm. 2011) might explain why Lekwungen also value hybrid systems containing more familiar edible species, such as potatoes, apples, plums and exotic blackberries (which have been established throughout the Pacific Northwest for more than a century). Camas, though, remains as an important symbol for cultural identity (Beckwith 2004; Turner 2005).

\section{Conclusions}

An ethnoecological restoration approach is most pertinent for investigating and exploring strategies and alternatives in heavily degraded cultural landscapes. Restoration strategies for Tl'chés built upon an adaptive framework embedded in TEKW and emerging social-ecological properties at Tl'chés. Moreover, a number of innovative strategies arose during restoration field activities.

Environmental change not only impacts ecosystems but might also have a predictable effect on cultural practices and memory. This is especially true for sensitive native species, which can be outcompeted by nonnative species in hybrid and novel ecosystems. Sometimes, nonnative species are incorporated into local peoples' ecological and cultural landscapes as seen in the heritage orchard at Tl'chés.

The value of adaptive management or adaptive restoration is not limited to novel or hybrid ecosystems. TEKW coevolved with local landscapes, ecosystems and species. Indigenous Peoples see the world through the lens of TEKW and adapt to environmental conditions through a process of trial and error and learning, which generates understanding of social-ecological processes (Berkes and Turner 2006). Therefore, non-native species assimilation is part of an adaptive practice to living on local landscapes.

Tl'chés poses important challenges with regards to TEKW renewal for land management. Although the islands are the best near-natural sites in the Lekwungen territory, and possibly in the entire region, they have been untended for more than 50 years. As a result of this process the local ecosystems are highly altered from their natural and historical states. Lekwungen people have only recently reconnected with the landscape. At present there are only a handful of knowledgeable Elders who experienced life on the islands before abandonment who are able to contribute insights for setting restoration goals. At the same time, youth are involved in the restoration process and taking the opportunity to connect with Elders and ecosystems through restoration work. Restoration facilitates genuine human engagement with ecosystems allowing opportunities for learning (Higgs and Hobbs 2010).

Finally, dynamic ecosystems within Indigenous territories have been managed and maintained for resource use, cultural practices and renewal, and maintenance of ecological services and biodiversity. Emerging novel ecological configurations in cultural landscapes pose challenges beyond adaptive thresholds, possibly threatening social-ecological resilience, and must be cautiously addressed. Yet managing or restoring novel ecosystems requires novel strategies and understandings for the effective management of these rapidly changing systems.

\section{Additional files}

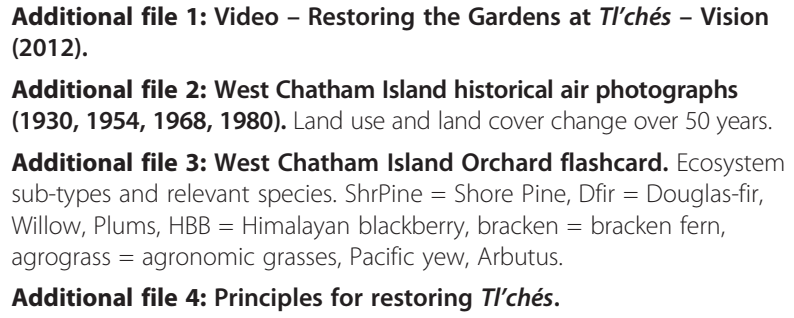

Additional file 2: West Chatham Island historical air photographs (1930, 1954, 1968, 1980). Land use and land cover change over 50 years.

Additional file 3: West Chatham Island Orchard flashcard. Ecosystem sub-types and relevant species. ShrPine = Shore Pine, Dfir = Douglas-fir, Willow, Plums, HBB = Himalayan blackberry, bracken = bracken fern, agrograss $=$ agronomic grasses, Pacific yew, Arbutus.

Additional file 4: Principles for restoring TI'chés.

\section{Abbreviations}

CDF: Coastal Douglas-fir; COSEWIC: Committee on the Status of Endangered Wildlife in Canada; CRD: Capital Regional District; GOERT: Garry Oak Ecosystem Recovery Team; TCEM: Terrestrial Cultural Ecosystem Mapping; TEKW: Traditional Ecological Knowledge And Wisdom.

\section{Competing interests}

The author declares that he has no competing interests.

\section{Authors' information}

Thiago C. Gomes (MA Environmental Studies, BSc. Biological Sciences) is an emerging Brazilian ethnoecologist based on the west coast of Canada and southern Brazil.

www.gothiago.com

\section{Acknowledgements}

I would like to thank Lekwungen elder Joan Morris, Sellemah, for sharing her vision for Tl'chés and her life experiences, and Dr. Nancy Turner and Dr. Eric Higgs from the School of Environmental Studies at the University of Victoria for exceptional supervision during this research project. I would also like to thank Andra Forney for assisting with language edits.

And finally, thanks to the Sarah Spencer Research Foundation (SPRF) and Social Sciences and Humanities Research Council (SSHRC) for funding this project.

Received: 13 December 2012 Accepted: 24 April 2013

Published: 11 June 2013 


\section{References}

Allen GB, Brown KJ, Hebda RJ (1999) Surface pollen spectra from southern Vancouver Island, British Columbia, Canada. Can J Bot 77:786-799

Anderson K (2005) Tending the wild: Native American knowledge and the management of California's natural resources. University of California Press, Berkley

Anderson K (2009) The Ozette prairies of Olympic National Park: their former Indigenous uses and management. Final Report to Olympic National Park, Port Angeles, Washington. USDA Natural Resources Conservation Service, Davis, CA

Asch M (1979) The ecological-evolutionary model and the concept of mode of production. In: Turner D, Smith G (eds) Challenging anthropology. McGraw Hill, Toronto

Beckwith B (2004) "The queen root of this clime": ethnoecological investigations of blue camas (Camassia leichtlinii (Baker) Wats., C. quamash (Pursh) Greene: Liliaceae) and its landscapes on southern Vancouver Island, British Columbia PhD Thesis. University of Victoria, Victoria

Berkes F, Turner NJ (2006) Knowledge, learning and the evolution of conservation practice for social-ecological system resilience. Hum Ecol 34(4):479-494

Berkes F, Colding J, Folke C (2000) Rediscovery of traditional ecological knowledge as adaptive management. Ecol Appl 10(5):1251-1262

Bernard HR (2002) Research methods in anthropology: qualitative and quantitative approaches, 3rd edn. Altamira Press, Walnut Creek

Boas F (1890) Preliminary notes on the Indians of BC. The Northwestern tribes of Canada, pp 233-255

Boyd R (1999) Indians, fire and the land in the Pacific Northwest. Conserv Biol 9:962-964

COSEWIC - Committee on the Status of Endangered Wildlife in Canada (2008) COSEWIC assessment and status report on the California Buttercup Ranunculus californicus in Canada. Committee on the Status of Endangered Wildlife in Canada, Ottawa, http://www.sararegistry.gc.ca/species/speciesDetails_e.cfm?sid=1025

CRD - Capital Regional District (2011) Regional community atlas, http://viewer. crdatlas.ca/public

Cunningham A (2001) Applied ethnobotany: people, wild plant use and conservation. Earthscan, London

Deur D, Turner NJ (eds) (2005) Keeping it living: traditions of plant use and cultivation on the northwestern coast of North America. UBC Press, Vancouver

Duff W (1969) The Fort Victoria Treaties. BC Studies. BC Studies might stand, Victoria

Fuchs MA (2001) Towards a recovery strategy for Garry oak and associated ecosystems in Canada: ecological assessment and literature review. Tech. Rep. GBEI/EC-00-030. Environment Canada. Canadian Wildlife Service, Vancouver

Garibaldi A, Turner NJ (2004) Cultural keystone species: implications for ecological conservation and restoration. Ecol Soc 9(3):

GOERT - Garry Oak Ecosystem Recovery Team (2010) Garry oak ecosystems: where do they exist?., http://www.goert.ca/about/

Gomes TC (2012) Restoring Tl'chés: an ethnoecological restoration study in Chatham Island, British Columbia. University of Victoria, Canada. Master Thesis

Hamann A (2006) Potential effects of climate change on ecosystem and tree species distribution in British Columbia. Ecol 87(11):2773-2786

Hebda RJ (1995) British Columbia vegetation and climate history with focus on 6 ka BP. Géogr Phys Quatern 49(1):55-79. doi:10.7202/033030ar

Herrick JE, Van Zee JW, Haystad KM, Burkett LM, Whitford WG (2005) Monitoring manual for grassland, shrubland and savanna ecosystems. Design, supplementary methods and interpretation. USDA - ARS Jordana Experimental Range, Las Cruces, New Mexico, Volume II

Heusser LE (1983) Palynology and paleoecology of postglacial sediments in an anoxic basin, Saanich Inlet, British Columbia. Can J Earth Scie 20:873-885

Higgs E (2003) Nature by Design: People, Natural Process and Ecological Restoration. MIT, London

Higgs E (2005) The two-culture problem: ecological restoration and the integration of knowledge. Restor Ecol 13:159-164

Higgs E, Hobbs R (2010) Wild design: principles to guide interventions in protected areas. In: Yung L, Cole N (eds) Beyond naturalness. Island Press, Washington, DC

Hill-Tout C (1905) Report on the ethnology of the south-eastern tribes of Vancouver Island. British Columbia, Royal Anthropological Institute, London
Hobbs RJ, Arico S, Aronson J, Brown JS, Bridgewater P, Cramer VA, Epstein PR, Ewel JJ, Klink CA, Lugo AE, Norton D, Ojima D, Richadson DM, Sanderson EW, Valladares F, Vila M, Zamora R, Zobel M (2006) Novel ecosystems: theoretical and management aspects of the new ecological world order. Global Ecol Biogeogr 15:1-7

Hobbs R, Higgs E, Harris A (2009) Novel ecosystems: implications for conservation and restoration. Trends Ecol Evol 24(11):500-605

Hobbs R, Hallet LM, Ehrlich PR, Mooney HA (2011) Intervention ecology: applying ecological science in the twenty-first century. BioSc 61(6):442-450

Jenness D (2999) Origin of salmon (and use of Indian consumption plant, or "Indian celery" - Lomatium nudicaule). Coast Salish Field Notes, Unpublished. Original Manuscript (No. 1103.6) in Ethnology Archives. National Museum of Civilization, Ottawa, Ontario, n.d. circa 1930s

Lea T (2006) Historical Garry oak ecosystems of Vancouver Island, British Columbia, pre-European contact to the present. Davidsonia 17(2):34-50

Lutz JS (2009) Makúk: a new history about aboriginal-white relations. UBC Press, Vancouver

MacDougall AS, Turkington R (2005) Are invasive species the drivers or passengers of change in degraded ecosystems? Ecology 86(1):42-55

MacDougall AS, Beckwith B, Maslovat C (2004) Defining conservation strategies with historical perspectives: a case study from a degraded oak grassland ecosystem. Conserv Biol 18(2):455-465

Maffi L, Woodley E (2010) Biocultural diversity conservation: a global sourcebook. Earthscan, London

McDadi O, Hebda RJ (2008) Change in historic fire disturbance in a Garry oak (Quercus garryana meadow and Douglas-fir (Pseudotsuga menziesii) mosaic, University of Victoria, British Columbia, Canada: a possible link with First Nations and Europeans. Fores Ecol Manag 256(10):1704-1710. doi:10.1016/j. foreco.2008.03.012

McKenna-McBride Royal Commission (1913) Transcript of evidence. June 10, 1913. Union of BC Indian Chiefs, http://gsdl.ubcic.bc.ca/cgi-bin/library.cgi?e=q-01000-

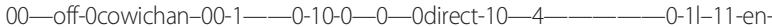
50-20-about-chatham-00-3-1-00-0-4-0-0-0-11-10-0utfZz-8-00\&a=d\&c= cowichan\&srp=0\&srn=0\&cl=search\&d=HASH01ef59559215f2fda22452ac.23.1. Accessed May, 2012

Millennium Ecosystem Assessment (2005) Ecosystems and human well-being: synthesis. Island Press, Washington, DC

Milton SJ (2003) Emerging ecosystems: a washing stone for ecologists, economists and sociologists? S Afr J Sci 99:404-406

Mitchell M (1968) A dictionary of Songish, a dialect of Straits Salish. University of Victoria, Victoria

Pellatt MG, Hebda RJ, Mathewes RW (2001) High-resolution Holocene vegetation history and climate from Hole 1034B, ODP leg 169S, Saanich Inlet, Canada. Mar Geol 174(1-4):211-222. doi:10.1016/S0025-3227(00)00151-1

Province of British Columbia (2010) Field manual for describing terrestrial ecosystems, 2nd edn. Land management handbook no. 25. BC Ministry of Environment, Victoria

Rogers-Martinez D (1992) The Sinkyone Intertribal Park project. Restor Manag Notes 10:64-69

Ryan GW, Bernard HR (2003) Techniques to identify themes. Field Meth 15(1):85-109

Society for Ecological Restoration International (2004) The SER international primer on ecological restoration. Science \& Policy Working Group. Version 2. SER, Washington DC

Suttles W (1951) The early diffusion of the potato among the Coast Salish. S J Anthropol 7(3):272-288

Suttles W (1974) Economic life of the Coast Salish of Haro and Rosario Straits. Garland, New York

Suttles W (2005) Coast Salish resource management: incipient agriculture? In: Deur D, Turner NJ (eds) Keeping it living: traditions of plant use and cultivation on the Northwest Coast of North America. University of Washington Press, Seattle

Turner NJ (1999) "Time to burn": traditional use of fire to enhance resource production by aboriginal peoples in British Columbia. In: Boyd R (ed) Indians, fire and the land in the Pacific Northwest. Oregon State University Press, Corvallis

Turner NJ (2005) Earth's blanket: traditional teachings for sustainable living. Douglas \& Mclntyre, Vancouver

Turner NJ, Gregory R, Brooks C, Failing L, Satterfield T (2008) From invisibility to transparency: identifying the implications (of invisible losses to First Nations communities). Ecol Soc 13(2):7 
Wang T, Campbell EM, O'Neill GA, Aitken SN (2012) Projecting future distributions of ecosystem climate niches: uncertainties and management applications. For Ecol Manag 279:128-140. doi:10.1016/j.foreco.2012.05.034

Ward P, Radcliffe G, Kirkby J, Illingworth J, Cadrin C (1998) Sensitive ecosystems inventory, East Vancouver Island and Gulf Islands, 1993-1997. Volume 1: methodology, ecological descriptions, and results. Technical Report Series No. 320. Canadian Wildlife Service, Pacific and Yukon Region, British Columbia, Vancouver

White R (1980) Land use and social change: the shaping of Island County. University of Washington Press, Seattle, Washington

doi:10.1186/2192-1709-2-15

Cite this article as: Gomes: Novel ecosystems in the restoration of cultural landscapes of TI'chés, West Chatham Island, British Columbia, Canada. Ecological Processes 2013 2:15.

Submit your manuscript to a SpringerOpen ${ }^{\circ}$ journal and benefit from:

- Convenient online submission

- Rigorous peer review

- Immediate publication on acceptance

- Open access: articles freely available online

- High visibility within the field

- Retaining the copyright to your article 